\title{
REPOSISI KEDUDUKAN JUSTICE COLLABORATOR DALAM UPAYA PEMBERANTASAN TINDAK PIDANA KORUPSI
}

\author{
Bahrudin Machmud, Muhammad Junaidi, Amri Panahatan Sihotang, Kukuh \\ Sudarmanto \\ Magister Hukum Universitas Semarang, Semarang \\ bahrudinmachmud@gmail.com
}

\begin{abstract}
Abstrak
Tujuan dari penelitian ini adalah untuk mengkaji dan memahami reposisi kedudukan justice collaborator dalam upaya pemberantasan tindak pidana korupsi. Justice Collaborator merupakan saksi pelaku yang mau bekerjasama dengan penegak hukum untuk mengungkap suatu tindak pidana. Bagaimana kedudukan justice collaborator dalam upaya pemberantasan tindak pidana korupsi dan bagaimana Reposisi kedudukan justice collaborator dalam upaya pemberantasan tindak pidana korupsi. Penelitian ini menggunakan Metode pendekatan yuridis normatif. Hasil penelitian ini adalah Kedudukan Justice Collaborator sebagai pelaku yang dijadikan sebagai saksi yang mau bekerjasama dengan penegak hukum dan pedoman penggunaannya diatur dalam Surat Edaran Mahkamah Agung Nomor 04 tahun 2011. Reposisi Kedudukan Justice Colllaborator adalah menempatkan Justice Colllaborator sebagai saksi kunci dalam peraturan perundang-undangan baru atau memasukkannya dalam undang-undang tentang upaya pemberantasan tindak pidana korupsi yang telah ada dan menempatkan Justice Collaborator sebagai saksi yang bisa di mintai keterangannya di luar sidang peradilan, sehingga para penyidik bisa lebih leluasa memperoleh keterangan dan informasi untuk membongkar pelaku lain dalam kasus tindak pidana korupsi.
\end{abstract}

Kata kunci : Kedudukan; Justice Collaborator; Tindak Pidana Korupsi. 


\title{
REPOSITION OF THE POSITION OF JUSTICE COLLABORATOR IN EFFORTS TO ERADICATE CORRUPTION
}

\begin{abstract}
The purpose of this research is to study and understand the repositioning of justice collaborators in an effort to eradicate corruption. Justice Collaborator is a perpetrator witness who is willing to cooperate with law enforcement to uncover a criminal act. What is the position of justice collaborator in an effort to eradicate corruption and how is the position of justice collaborator in an effort to eradicate corruption. This study uses a normative juridical approach. The result of this research is the position of Justice Collaborator as an actor who is used as a witness who is willing to cooperate with law enforcement and the guidelines for its use are regulated in Supreme Court Circular Number 04 of 2011. The Repositioning of Justice Colllaborator is placing Justice Collaborators as key witnesses in new legislation or include it in the law on efforts to eradicate existing corruption crimes and place Justice Collaborators as witnesses who can be questioned outside of court, so that investigators can more freely obtain information and information to expose other perpetrators in cases of criminal corruption.
\end{abstract}

Keywords: Position; Justice Collaborator; Corruption Crime. 


\section{A. PENDAHULUAN}

Permasalahan tentang korupsi di Indonesia masih menjadi pekerjaan rumah tangga yang sangat sulit untuk diselesaikan, walaupun kita tau sudah ada beberapa peraturan perundang-undangan yang mengatur secara khusus tentang tindak pidana tersebut. Berbicara tentang Tindak Pidana, di Indonesia sendiri mulai di kenal dengan istilah "strafbaar feit" yang merupakan istilah dari bahasa Belanda. Keberadaan istilah tersebut terdapat dalam KUHP Hindia Belanda (Wetboek van Strafrecht) namun dalam kitab tersebut tidak menjelaskan secara jelas tentang istilah"strafbaar feit", sehingga pada akhirnya para ahli hukum di Indonesia berusaha memberi arti dan isi dari istilah tersebut.

Menurut Moeljatno, “tindak pidana adalah perbuatan yang dilarang oleh suatu aturan hukum larangan mana disertai ancaman (sanksi) yang berupa pidana tertentu, bagi barang siapa yang melanggar larangan tersebut". ${ }^{1}$ Sedangkan, Menurut Pompe, "secara teoritis tindak pidana dapat dirumuskan sebagai suatu pelanggaran norma (gangguan terhadap tertib hukum) yang dengan sengaja maupun tidak disengaja telah dilakukan oleh seorang pelaku, dimana penjatuhan hukuman terhadap pelaku tersebut adalah perlu demi terpeliharanya tertib hukum dan terjaminnya kepentingan hukum". ${ }^{2}$ Subjek tindak pidana yang dikenal dalam KUHP adalah orang perorangan. Dengan kata lain, hanya manusia yang dapat melakukan tindak pidana dan hanya manusia yang dapat dituntut serta dibebani pertanggungjawaban pidana. $^{3}$

Akibat yang ditimbulkan dari perbuatan korupsi sangatlah berbahaya untuk stabilitas dan keamanan negara. Korupsi bisa mempengaruhi dalam segala bidang dan sektor kehidupan masyarakat secara luas. Tindak pidana korupsi yang bisa membudidaya di negeri ini dapat menjadikan timbulnya krisis ekonomi, rusaknya nilai-nilai demokrasi dan nilai moralitas bangsa. ${ }^{4}$

Penelitian ini terkait dengan penelitian Manalu (2015) tentang “Justice Collaborator Dalam Tindak Pidana Korupsi”. Hasil dari penelitian ini adalah Di

${ }^{1}$ Mahrus Ali, Dasar-Dasar Hukum Pidana, Sinar Grafika, Jakarta, 2011, hlm. 97

2 P.A.F. Lamintang, Dasar-Dasar Hukum Pidana Indonesia, Citra Aditya Bakti, Bandung, 1997, hlm. 182

${ }^{3}$ Rizqi Purnama Puteri, Muhammad Junaidi, Zaenal Arifin, "Reorientasi Sanksi Pidana Dalam Pertanggungjawaban Korporasi Di Indonesia”, Jurnal USM Law Review 3 (1), 2020, hlm 102. DOI : $\underline{10.26623 / j u l r . v 3 i 1.2283}$

${ }^{4}$ Rika Ekayanti, "Perlindungan Hukum Terhadap Justice Collaborator Terkait Penanganan Tindak Pidana Korupsi di Indonesia”, Jurnal Magister Hukum Udanaya 4 (1), 2015, hlm. 138 
berbagai negara, bentuk perlindungan hukum yang diberikan terhadap saksi Justice Collaborator dan saksi whistleblower berbeda-beda di negara satu dan lainnya, di negara Italia menjadi awal terjadinya perlindungan hukum kepada seorang Justice Collaborator. Selanjutnya menyusul negara Amerika dan Australia tentang perlindungan hukum terhadap Justice Collaborator. Di Indonesia sendiri pengaturan tentang Justice Collaborator terdapat pada peraturan yang disusun bersama oleh para penegak hukum dan termuat juga didalam surat edaran. Menyikapi kejahatan korupsi yang terjadi para negara-negara didunia mengatur secara ketat tentang pemberantasan tindak pidana tersebut dan pengaturan secara jelas tentang Justice Collaborator dan Whistleblower. Sedangkan negara Indonesia sendiri pengaturan tentang Justice Collaborator dan Whistleblower hanya terdapat dengan jelas dalam peraturan bersama dan Surat edaran. ${ }^{5}$

Penelitian Muhammad (2015) tentang "Pengaturan dan Urgensi Whistleblower dan Justice Collaborator dalam Sistem Peradilan Pidana”. Hasil penelitian ini menunjukkan ada empat urgensi penggunaan Whistleblower dan Justice Collaborator. Pertama, pada tahap penyelidikan dan penyidikan keduanya sangat membantu dalam hal pemberian informasi tentang kejahatan dan pengungkapan para pelaku lainnya. Kedua, pada tahap penuntutan, informasi yang diberikan keduanya diharapkan bisa menjadi dasar yang kuat untuk pemeriksaan dalam persidangan. Ketiga, pada tahap pemeriksaan dalam persidangan diharapkan bisa memberikan bukti-bukti yang kuat untuk membongkar atau mengungkap suatu kejahatan. Keempat, pada tahap pelaksanaan putusan, dapat membantu pengungkapan pelaku lainnya dan bisa membantu dalam pengembalian aset yang diperoleh dari suatu kejahatan. ${ }^{6}$

Sedangkan penelitian lainnya yaitu penelitian Syafruddin (2013) tentang "Perlindungan Hukum Terhadap Whistleblower Dan Justice Collaborator Dalam Upaya Pemberantasan Tindak Pidana Korupsi”. Hasil penelitian ini menerangkan bahwa perusahaan-perusahaan besar baik BUMN maupun swasta, telah menerapkan bentuk perlindungan bagi seorang whistleblower dan justice collaborator.Penerapan

\footnotetext{
${ }^{5}$ River Yohanes Manalu, “Justice Collaborator Dalam Tindak Pidana Korupsi”, Jurnal Lex Crime 4 (1), 2015.

${ }^{6}$ Rusli Muhammad, "Pengaturan dan Urgensi Whistle Blower dan Justice Collaborator dalam Sistem Peradilan Pidana”, Jurnal Hukum IUS QUIA IUSTUM 22 (2), 2015.
} 
sistem whistleblowing telah dilakukan oleh perusahaan- perusahaan diantaranya Pertamina, Lembaga Kebijakan Barang dan Jasa, Komisi Pemberantasan Korupsi yang produknya adalah KWS (KPK Whistleblowing System) dan Komite Nasional Kebijakan Governance (KNKG). Akan tetapi, dari semua praktek perlindungan tersebut ternyata masih ada kelemahan di bidang regulasi. Belum adanya payung hukum secara umum yang dapat dijadikan dasar yang jelas untuk melakukan perlindungan terhadap seorang whistleblower dan justice collaborator dalam proses peradilan. $^{7}$

Penelitian ini sendiri membahas tentang Kedudukan Justice Collaborator dalam Upaya Pemberantasan Tindak Pidana Korupsi dan Reposisi Kedudukan Justice Collaborator dalam Upaya Pemberantasan Tindak Pidana Korupsi. Perbedaan penelitian ini dengan penelitian yang telah lalu ialah penulis lebih memfokuskan pembahasan tentang keberadaan seorang Justice Collaborator dalam peraturan perundang-undangan yang telah ada, penulis melihat saat ini masih ada beberapa kasus tindak pidana korupsi yang diterima penggunaan jasa seorang Justice Collaborator dan ada juga yang ditolak penggunaannya. Masih ada para penegak hukum yang berbeda pandangan mengenai penetapan seseorang menjadi Justice Collaborator. Hal tersebut mengakibatkan seorang pelaku yang ingin bekerjasama dengan penegak hukum untuk membongkar suatu tindak pidana akan menjadi ragu untuk bekerjasama. Untuk tujuan dari penelitian pada artikel ini adalah untuk mengkaji dan memahami kedudukan Justice Collaborator dalam upaya pemberantasan tindak pidana korupsi dan untuk mengkaji dan memahami reposisi kedudukan Justice Collaborator dalam upaya pemberantasan tindak pidana korupsi

\section{B. PERMASALAHAN}

Berdasarkan latar belakang yang telah dijabarkan diatas, maka rumusan masalah dalam artikel ini adalah sebagai berikut:

1. Bagaimana kedudukan Justice Collaborator dalam upaya pemberantasan tindak pidana korupsi?

2. Bagaimana reposisi kedudukan Justice Collaborator dalam upaya pemberantasan tindak pidana korupsi?

${ }^{7}$ Nixson Syafruddin, Kalo Tan Kamello, Mahmud Mulyadi, "Perlindungan Hukum Terhadap Whistleblower Dan Justice Collaborator Dalam Upaya Pemberantasan Tindak Pidana Korupsi", USU Law Journal 2 (2), 2013. 


\section{METODE PENELITIAN}

Metode pendekatan yang digunakan dalam penelitian ini adalah "metode pendekatan undang-undang (statute approach)/yuridis normatif”. Pendekatan dilakukan dengan menelaah semua Undang-Undang dan regulasi yang berkaitan dengan isu dan permasalahan-permasalahan hukum yang sedang ditangani. ${ }^{8}$ "Pendekatan yuridis normatif dalam penelitian ini bermaksud melakukan reorientasi dan evaluasi terhadap pengaturan justice collaborator yang sudah diatur dalam perundang-undangan saat ini”.

Penelitian ini menggunakan spesifikasi deskriptif yang artinya adalah "penggambaran suatu masalah dalam penelitian ini diambil dari hal-hal secara khusus atau konkrit saja, dengan melihat secara jelas keadaan dari objek penelitian tanpa memperhatikan hal-hal yang bersifat umum". Penelitian ini diharapkan memperoleh gambaran dan uraian yang jelas, secara rinci, sistematis dan menyeluruh mengenai kedudukan justice collaborator dalam upaya pemberantasan tindak pidana korupsi.

Data yang digunakan dalam penelitian ini menitikberatkan pada data sekunder. Sedangkan data primer lebih bersifat penunjang. Adapun pembagian data sekunder dibagi menjadi tiga bagian yaitu bahan hukum primer, bahan hukum sekunder dan bahan hukum tersier. Data-data ini diambil dengan cara penelitian kepustakaan (Library Research). Sedangkan metode analisis data dalam penelitian ini adalah data kualitatif.

Teori yang digunakan dalam penelitian ini adalah Teori Sistem Hukum (Legal Theory) oleh Lawrence M. Friedman, Teori Hierarki Perundang-Undangan oleh Hans Kelsen, dan Teori Trias Politica oleh Montesquieu.

\section{HASIL DAN PEMBAHASAN}

\section{Kedudukan Justice Collaborator Dalam Upaya Pemberantasan Tindak Pidana Korupsi}

Pengaturan Justice Colllaborator sendiri dalam perundang-undangan di Indonesia masih belum diatur secara jelas dan terperinci. Penulis dalam hal ini mencoba memaparkan ada beberapa peraturan perundang-undangan yang secara

\footnotetext{
hlm. 93-95.

${ }^{8}$ Peter Mahmud Marzuki, “Penelitian Hukum”, Kencana Prenada Media Group, Jakarta, 2005,

${ }^{9}$ Soerjono Soekanto, 1981, “Pengantar Penelitian Hukum”, Jakarta: UI Press, hlm. 10.
} 
tersirat mengatur tentang keberadaan Justice Colllaborator . Peraturan perundangundangan tersebut diantaranya adalah sebagai berikut:

1) Undang-undang Nomor 31 Tahun 1999 tentang Pemberantasan Tindak Pidana Korupsi yang telah diperbaharui dengan Undang-undang Nomor 20 Tahun 2001 tentang Perubahan atas Undang-undang Nomor 31 Tahun 1999

Pembahasan dalam Undang-undang ini tentang setiap orang atau pihakpihak yang bekerjasama dengan penegak hukum dan membatu dalam proses pemberantasan tindak pidana korupsi maka pihak tersebut akan mendapatkan penghargaan atau reward. Pengaturan ketentuan tersebut diatur dalam Pasal 42 ayat (1) Undang-undang Nomor 31 Tahun 1999 tentang Pemberantasan Tindak Pidana Korupsi dan telah diperbaharui dengan Undang-undang Nomor 20 Tahun 2001. Pada intinya bunyi pasal tersebut menyatakan "Pemerintah memberikan penghargaan kepada anggota masyarakat yang telah berjasa membantu upaya pencegahan, pemberantasan, atau pengungkapan tindak pidana korupsi." 10

2). Undang-undang Nomor 31 Tahun 2014 tentang Perubahan Atas Undangundang Nomor 13 Tahun 2006 Tentang Perlindungan Saksi dan Korban

Pemaparan lebih jelas tentang Justice Colllaborator dalam UndangUndang nomor 31 tahun 2014 ini terdapat pada pasal 10 dan pasal 10A, pasalpasal tersebut menyatakan tentang kekuatan dan akibat dari kesaksian dari saksi pelaku serta menyatakan tentang penanganan khusus dan pemberian penghargaan kepada seorang saksi pelaku atas kesaksian yang diberikan. ${ }^{11}$

Seorang saksi yang juga menjadi seorang tersangka dalam kasus tindak pidana yang sama, tidak dapat dibebankan tuntutan pidana apabila dia dinyatakan secara sah dan meyakinkan bersalah. Akan tetapi kesaksian yang diberikan oleh saksi pelaku dapat dijadikan pertimbangan hakim untuk meringankan penjatuhan pidana. ${ }^{12}$

\footnotetext{
${ }^{10}$ Undang-undang Nomor 31 Tahun 1999 tentang Pemberantasan Tindak Pidana Korupsi yang telah diperbaharui dengan Undang-undang Nomor 20 Tahun 2001 tentang Perubahan atas Undangundang Nomor 31 Tahun 1999.

${ }^{11}$ Undang-undang Nomor 31 Tahun 2014 tentang Perubahan Atas Undang-undang Nomor 13 Tahun 2006 Tentang Perlindungan Saksi dan Korban.

12 Kadek Yolanda Zara Octavany, Ni Ketut Sri Utari, “Eksistensi Dan Perlindungan Hukum Terhadap Whistleblower Dan Justice Collaborator Dalam Upaya Penanggulangan Organized Crime di Indonesia Pada Masa Mendatang”, Jurnal Hukum Kertha Wicara 5, hlm. 4.
} 
Undang-undang tersebut mengindikasikan bahwa pertimbangan hakim dalam meringankan penjatuhan pidana hanya bergantung pada kontribusi yang diberikan seorang Justice Collaborator. Hal tersebut dapat disimpulkan bahwa ketentuan yang ada tidak dapat mengikat dan mewajibkan seorang hakim untuk memberikan keringanan pidana kepada seorang Justice Collaborator, sehingga dapat dipastikan tidak ada jaminan seorang Justice Collaborator mendapat keringanan pidana. $^{13}$

3). Konvensi Perserikatan Bangsa-Bangsa Anti-korupsi Tahun 2003 (United

\section{Nation Convention Against Corruption)}

Konvensi ini menyatakan bahwa setiap negara harus mempertimbangkan pemberian kekebalaan dalam proses penuntutan kepada para pihak atau orang yang mau bekerjasama untuk memberikan informasi yang penting dan berguna untuk proses penyelidikian maupun penuntutan. Pernyataan tersebut termuat dalam pasar 37 ayat (3) Konvensi Perserikatan Bangsa-bangsa Anti-Korupsi Tahun 2003. ${ }^{14}$

4). SEMA Nomor 4 Tahun 2011 tentang Perlakuan bagi Pelapor Tindak Pidana (whistleblower) dan Saksi Pelaku yang Bekerjasama (Justice Colllaborator) di dalam Perkara Tindak Pidana Tertentu.

SEMA ini memberikan beberapa ketentuan tentang pedoman penggunaan seorang Justice Collaborator. Berdasarkan Angka 9 huruf (a) dan (b), untuk menjadi seorang Justice Collaborator ada beberapa ketentuan yang harus dipenuhi. Pertama, Orang yang bersangkutan bukan merupakan pelaku utama, mau mengakui kejahatannya tersebut, tindak pidana yang dilakukan adalah tindak pidana tertentu contohnya korupsi, mau memberikan keterangan di sidang pengadilan. Kedua, Jaksa penuntut umum menyatakan dalam tuntutannya orang yang bersangkutan telah memberikan informasi yang penting dan berguna untuk mengungkap kejahatan tersebut, membantu mengungkap pelaku yang memiliki peran lebih besar, dan mau mengembalikan semua aset yang diperoleh dari suatu

${ }^{13}$ Claudhya C. Coloay, "Perlindungan Hukum Terhadap Justice Collaborator Dalam Tindak Pidana Pencucian Uang Menurut UU No. 31 Tahun 2014 Tentang Perlindungan Saksi Dan Korban", Jurnal Lex Crime 7 (1), 2018, hlm. 7.

${ }^{14}$ Konvensi Perserikatan Bangsa-Bangsa Anti-korupsi Tahun 2003 (United Nation Convention Against Corruption) 
kejahatan tersebut. ${ }^{15}$

5). Peraturan Bersama yang dilakukan oleh Menkumham, Jaksa Agung, Kapolri, KPK, dan Ketua LPSK Nomor M.HH-11.HM.03.02.th.2011, Nomor PER045/A/JA/12/2011, Nomor 1 Tahun 2011, Nomor KEPB-02/01- 55/12/2011, Nomor 4 Tahun 2011 tentang Perlindungan bagi Pelapor, Saksi Pelapor, dan Saksi Pelaku yang Bekerjasama

Tujuan dari pembentukan peraturan bersama ini adalah tak lain untuk memberikan pedoman bagi para penegak hukum dan menyamakan pandangan antara para penegak hukum berkaitan tentang permasalahan permberian perlindungan hukum bagi para saksi pelapor dan para saksi yang mau bekersama dalam mengungkap suatu tindak pidana. Dengan adanya peraturan bersama ini, kejahatan yang bersifat serius dan terorganisir harapannya bisa terungkap dan para penegak hukum dapat dipermudah memperoleh informasi yang berguna dari para saksi pelapor maupun saksi yang bekerjasama.

Jika ditinjau dari teori sistem hukum (The Legal System) menurut Lawrence M. Friedman bisa di lihat dari tiga komponen utama yaitu Substansi hukum (legal substance), Struktur hukum (legal structure), dan Budaya hukum (legal culture). ${ }^{16}$

Substansi hukum (legal substance) dalam masalah ini pengaturan Justice Colllaborator terdapat dalam beberapa undang-undang yang ada, undang-undang tersebut yaitu Undang-undang Nomor 31 Tahun 1999 tentang Pemberantasan Tindak Pidana Korupsi yang telah diperbaharui dengan Undang-undang Nomor 20 Tahun 2001 tentang Perubahan atas Undang-undang Nomor 31 Tahun 1999, Undang-undang Nomor 31 Tahun 2014 tentang Perubahan Atas Undang-undang Nomor 13 Tahun 2006 Tentang Perlindungan Saksi dan Korban yang didalamnya terdapat pengaturan mengenai perlindungan terhadap saksi pelaku (Justice Colllaborator ), Konvensi Perserikatan Bangsa-Bangsa Anti-korupsi Tahun 2003 (United Nation Convention Against Corruption), Surat Edaran Mahkamah Agung Nomor 4 Tahun 2011 tentang Perlakuan bagi Pelapor Tindak Pidana (whistleblower) dan Saksi Pelaku yang Bekerjasama (Justice Colllaborator) di dalam Perkara Tindak Pidana Tertentu, dan Peraturan Bersama yang dilakukan oleh

\footnotetext{
${ }^{15}$ Hendra Budiman, “Kesaksian”, Jurnal LPSK, Jakarta, 2016, hlm. 8.

${ }^{16}$ Lawrence M. Friedman, Sistem Hukum Perspektif Ilmu Sosial, (Bandung: Nusa Media,
} 2011), hlm. 8 . 
Menkumham, Jaksa Agung, Kapolri, KPK, dan Ketua LPSK Nomor M.HH11.HM.03.02.th.2011, Nomor PER-045/A/JA/12/2011, Nomor 1 Tahun 2011, Nomor KEPB-02/01- 55/12/2011, Nomor 4 Tahun 2011 tentang Perlindungan bagi Pelapor, Saksi Pelapor, dan Saksi Pelaku yang Bekerjasama.

Selanjutnya ditinjau dari Struktur hukum (legal structure), yang diartikan sebagai kerangka, bagian yang tetap bertahan, bagian yang memberikan semacam bentuk dan batasan terhadap keseluruhan instansi-instansi penegak hukum. Dalam upaya pemberantasan tindak pidana korupsi struktur hukum /pranata hukum yang ada di Indonesia adalah Komisi Pemberantasan Tindak Pidana Korupsi, Kepolisian, Kejaksaan, dan Lembaga Perlindungan Saksi dan Korban (LPSK).

Ditinjau dari Budaya hukum (legal culture) yang merupakan opini-opini, kepercayaan-kepercayaan (keyakinan-keyakinan), kebiasaan-kebiasaan, cara berfikir, dan cara bertindak, baik dari para penegak hukum maupun dari warga masyarakat, tentang hukum dan berbagai fenomena yang terkait dengan hukum. Pada upaya pemberantasan tindak pidana korupsi dengan menggunakan seorang Justice Colllaborator budaya hukum yang relevan dengan hal tersebut yaitu tentang pemenuhan hak-hak bagi seorang Justice Colllaborator. Hak-hak yang harus diterima seoarang Justice Colllaborator sudah diatur dalam regulasi, namun dalam implemantasinya masih berantakan. Para penegak hukum masih ada yang menyalahgunakan penggunaan regulasi yang ada sehingga terjadilah penyelewengan-penyelewengan.

Hubungan antara ketiga unsur sistem hukum tersebut sangat berpengaruh terhadap keberadaan Justice Colllaborator sebagai upaya pemberantasan tindak pidana korupsi. Dalam subtansi hukum keberadaan seorang Justice Colllaborator tidak diatur secara jelas dan terperinci, namun hanya diatur dalam peraturan pendukung yang berbentuk Surat Edaran. Akibatnya Hal tersebut berpengaruh pada struktur hukum yang kekurangan dasar yang jelas untuk menggunakan Justice Colllaborator sebagai alat pengungkap tindak pidana korupsi. Sehingga terjadilah budaya hukum yang kurang baik di dalam sistem hukum di Indonesia.

Justice Collaborator dalam perkembangannya harus mendapatkan perhatian khusus mengingat jasa yang diberikannya sangat membantu para penegak hukum 
dalam mengungkap kejahatan yang sulit dicari pembuktiannya. Peran kunci yang dimiliki seorang Justice Collaborator diantaranya untuk mengungkap tindak pidana yang telah terjadi maupun yang akan terjadi sehingga aset negara tetap aman, memberikan informasi penting kepada para penegak hukum, dan memberikan kesaksian dalam proses peradilan. ${ }^{17}$

\section{Reposisi Kedudukan Justice Collaborator Dalam Upaya Pemberantasan Tindak Pidana Korupsi}

Aspirasi masyarakat untuk memberantas korupsi semakin meningkat, karena korupsi telah menimbulkan kerugian yang sangat besar.Untuk itu upaya pencegahan dan pemberantasan korupsi perlu semakin ditingkatkan dan diintensifkan dengan tetap menjunjung tinggi hak asasi manusia dan kepentingan masyarakat.Untuk dapat memberantas korupsi diperlukan lembaga independen yang bebas dari pengaruh kekuasaan negara. ${ }^{18}$

Keberadaan Justice Collaborator merupakan salah satu terobosan hukum dalam upaya pemberantasan tindak pidana korupsi mengingat kasus tersebut merupakan serious crime dan scandal crime. Skala yang meluas dan modus yang canggih dari kasus-kasus tersebut membutuhkan cara-cara yang baru dan alat bantu yang efektif, karena cara-cara konvesional dirasa sulit dan kurang efektif dalam menyelesaikan kasus-kasus ini. ${ }^{19}$

Namun peraturan perundang-undangan yang ada seperti Undang-Undang Pemberantasan Tindak Pidana Korupsi, Undang-Undang Komisi Pemberantasan Tindak Pidana Korupsi, dan beberapa Undang-undang yang berkaitan dengan upaya pemberantasan tindak pidana korupsi justru menimbulkan problematika hukum dan benturan kewenangan kelembagaan mengenai pemahaman konsepasi ataupun implementasinya. Tentu arah formulasi kebijakan hukum tentang perubahan Undang-Undang yang berlaku tersebut tak bisa dihindari, untuk mencapai keselarasan yang diinginkan bersama.

${ }^{17}$ Dwi Oktafia Ariyanti dan Nita Ariyani, "Model Perlindungan Hukum Terhadap Justice Collaborator Tindak Pidana Korupsi di Indonesia”, Jurnal Hukum Ius Quia Iustum 27 (2) 2, 2020, hlm. 328.

18 Aryas Adi Suyanto, "Komisi Pemberantasan Korupsi Sebagai Lembaga Rasuah Dalam Pemberantasan Tindak Pidana Korupsi Di Indonesia", Jurnal USM Law Review 1 (1) 2018, hlm 59. DOI : $10.26623 /$ julr.v1i1.2231

19 Firman Wijaya, "Whistle Blower dan Justice Collaborator Dalam Perspektif Hukum", Penaku, Jakarta, 2012, hlm. 10. 
Pada perkembangannya munculah Surat Edaran Mahkamah Agung Nomor 04 tahun 2011 tentang Perlakuan Bagi Pelapor Tindak Pidana (whistleblower) dan Saksi Pelaku yang Bekerjasama (Justice Colllaborator) di dalam Perkara Tindak Pidana Tertentu, dalam SEMA ini menyebutkan dengan jelas mengenai bagaimana pedoman penerapan seseorang bisa dijadikan sebagai Justice Collaborator.

Dasar hukum Mahkamah Agung dalam mengeluarkan SEMA dapat kita lihat dalam Pasal 79 Undang-Undang No. 14 Tahun 1985 tentang Mahkamah Agung. Dalam Pasal 79 Undang-Undang No. 14 Tahun 1985, Mahkamah Agung diberikan kewenang untuk membentuk aturan sendiri atau rule making power. Tujuan dari undang-undang ini untuk memberikan kewenangan kepada Mahkamah Agung dalam menyeleasikan permasalahan-permasalahan yang belum diatur penyelesaiannya dalam undang-undang yang berlaku. Akan tetapi tidak semua produk surat edaran Mahkamah Agung bisa dijadikan sebagai rule making power. Hanya surat edaran Mahkamah Agung yang isinya mengatur hukum acara dan mengisi kekosongan hukum.

Berdasarkan ketentuan pasal 7 Undang-Undang No. 12 Tahun 2011 tentang Pembentukan Peraturan Perundang Undangan-undangan, yang termasuk dalam peraturan perundang-undangan meliputi Undang-Undang Dasar Negara Republik Indonesia Tahun 1945, Ketetapan Majelis Permusyawaratan Rakyat, Undangundang/Peraturan Pemerintah Pengganti Undang-undang, Peraturan Pemerintah, Peraturan Presiden, Peraturan Daerah Provinsi, dan Peraturan Daerah Kabupaten/Kota.

Pada ketentuan pasal 8 ayat (1) Undang-undang Nomor 12 Tahun 2011 menyatakan bahwa ada jenis-jenis peraturan perundang-undangan lainnya diluar dari ketujuh jenis peraturan perundang-undangan yang telah disebutkan dalam pasal 7. Adapun pembagian jenis-jenis peraturan tersebut meliputi peraturan yang ditetapkan oleh Majelis Permusyawaratan Rakyat, Dewan Perwakilan Rakyat, Dewan Perwakilan Daerah, Mahkamah Agung, Mahkamah Konstitusi, Badan Pemeriksa Keuangan, Komisi Yudisial, Bank Indonesia, Menteri, badan, lembaga, atau komisi yang setingkat yang dibentuk dengan Undang-Undang atau Pemerintah atas perintah Undang-Undang, Dewan Perwakilan Rakyat Daerah Provinsi, 
Gubernur, Dewan Perwakilan Rakyat Daerah Kabupaten/Kota, Bupati/Walikota, Kepala Desa atau yang setingkat.

Selanjutnya, ketentuan mengenai batasan-batasan yang harus diperhatikan oleh para pejabat atau lembaga dalam pembentukan peraturan perundang-undangan harus sesuai dengan perintah dari peraturan perundang-undangan yang lebih tinggi atau dibentuk berdasarkan kewenangan lembaga. Jika semua itu telah sesuai maka peraturan perundang-undangan yang telah dibentuk dapat diakui keberadaannya. Ketentuan tersebut diatas telah termuat dalam pasal 8 ayat (2) Undang-undang Nomor 12 Tahun 2011. ${ }^{20}$

Jika ditinjau dari Teori Hierarki Perundang-Undangan menurut Hans Kelsen norma-norma hukum itu berjenjang-jenjang dan berlapis-lapis dalam suatu hierarki (tata susunan), dalam arti, suatu norma yang lebih rendah berlaku, bersumber dan berdasar pada norma yang lebih tinggi, norma yang lebih tinggi berlaku, bersumber dan berdasar pada norma yang lebih tinggi lagi, demikian seterusnya sampai pada suatu norma yang tidak dapat ditelusuri lebih lanjut dan bersifat hipotesis dan fiktif yaitu Norma Dasar (Grundnorm). Teori Hans Kelsen ini kemudian dikembangkan oleh muridnya yang bernama Hans Nawiasky. Menurut teori Nawiasky, selain norma itu berlapis-lapis dan berjenjang-jenjang, norma itu juga dikelompokkan dalam empat kelompok yaitu Norma fundamental negara (Staatsfundamentalnorm), Aturan dasar negara (Staatsgrundgesetz), UndangUndang formal (Formell Gesetz), dan Peraturan pelaksanaan dan peraturan otonom (Verordnung En Autonome Satzung ${ }^{21}$ ). Dan di Indonesia hierarki peraturan perundang- undangan termuat dalam Undang-Undang No. 12 Tahun 2011 tentang Pembentukan Peraturan Perundang Undangan-undangan.

Maka berdasarkan teori tersebut, keberadaan Surat Edaran Mahkamah Agung Agung Nomor 04 tahun 2011 tentang Perlakuan Bagi Pelapor Tindak Pidana (whistleblower) dan saksi pelaku yang bekerjasama (Justice Colllaborator) dengan melihat ketentuan dalam pasal 8 Undang-Undang No. 12 Tahun 2011. Bahwa meskipun pada kenyataanya isi dari Surat Edaran Mahkamah Agung sebagian besar

20 Undang-Undang Nomor 12 Tahun 2012 tentang Pembentukan Peraturan Perundang Undangan-Undangan

${ }^{21}$ Muhammad Junaidi, “Teori Perancangan Hukum”, Universitas Semarang Press, 2021, Semarang, hlm. 93-94. 
berfungsi sebagai peraturan kebijakan (beleidsregel), namun karena dasar pembentukannya didasari oleh perintah pasal 79 Undang-Undang Mahkamah Agung. Maka SEMA dapat digolongkan sebagai peraturan perundang- undangan dan memiliki kekuatan hukum mengikat seperti yang ditentukan dalam pasal 8 ayat 2 Undang-Undang Nomor 12 Tahun 2011. Sedangkan dilihat dari segi kewenangan Surat Edaran Mahkamah Agung dibentuk berdasarkan kewenangan pengaturan yang dimiliki oleh Mahkamah Agung. Pengaturan tersebut berkaitan dengan fungsi lainya yaitu administrasi, nasehat, pengawasan, dan peradilan.

\section{E. PENUTUP}

Kedudukan seoarang Justice Colllaborator dalam upaya pemberantasan tindak pidana korupsi adalah sebagai pelaku yang dijadikan sebagai saksi yang mau bekerjasama dengan penegak hukum untuk memberikan bukti-bukti penting dan informasi-informasi yang diperlukan dalam membongkar dan memberantas tindak pidana korupsi serta telah diatur pedoman penggunaannya dalam Surat Edaran Mahkamah Agung Nomor 04 tahun 2011. Namun dalam kenyataannya masih terjadi perbedaan diantara para penegak hukum dalam menetapkan seseorang menjadi Justice Collaborator. Sehingga hal tersebut mengakibatkan perlindungan hukum dan pemberian reward tidak bisa didapatkan dan pada akhirnya para pelaku akan berfikir ulang untuk bekerjasama dengan penegak hukum. Sedangkan untuk reposisi kedudukan Justice Colllaborator dalam upaya pemberantasan tindak pidana korupsi adalah menempatkan Justice Colllaborator sebagai saksi kunci dalam peraturan perundang-undangan baru atau memasukkannya dalamundang-undang tentang upaya pemberantasan tindak pidana korupsi yang telah ada dan menempatkan Justice Collaborator sebagai saksi yang bisa di mintai keterangannya di luar sidang peradilan, sehingga para penyidik bisa lebih leluasa memperoleh keterangan dan informasi untuk membongkar pelaku lain dalam kasus tindak pidana korupsi. 


\section{DAFTAR PUSTAKA}

\section{Buku}

Ali, Mahrus, 2011, “Dasar-Dasar Hukum Pidana”, Jakarta, Sinar Grafika

Junaidi, Muhammad, 2021, "Teori Perancangan Hukum”, Semarang, Universitas Semarang Press

Lawrence M. Friedman, 2011, "Sistem Hukum Perspektif Ilmu Sosial”, Bandung: Nusa Media

Marzuki, Peter Mahmud, 2005, "Penelitian Hukum”, Jakarta: Kencana Prenada Media Group

P.A.F. Lamintang, 1997," Dasar-Dasar Hukum Pidana Indonesia”, Bandung, Citra Aditya Bakti

Soekanto, Soerjono, 1981, “Pengantar Penelitian Hukum”, Jakarta: UI Press

Wijaya, Firman, 2012, "Whistle Blower dan Justice Collaborator Dalam Perspektif Hukum”, Jakarta: Penaku.

\section{Jurnal}

Ariyanti, Dwi Oktafia dan Nita Ariyani, "Model Perlindungan Hukum Terhadap Justice Collaborator Tindak Pidana Korupsi di Indonesia”, Jurnal Hukum Ius Quia Iustum 27 (2), 2020.

Aryas Adi Suyanto, “Komisi Pemberantasan Korupsi Sebagai Lembaga Rasuah Dalam Pemberantasan Tindak Pidana Korupsi Di Indonesia", Jurnal USM Law Review 1 (1) 2018. DOI : 10.26623 julr.v1i1.2231

Coloay, Claudhya C., "Perlindungan Hukum Terhadap Justice Collaborator Dalam Tindak Pidana Pencucian Uang Menurut UU No. 31 Tahun 2014 Tentang Perlindungan Saksi Dan Korban”, Jurnal Lex Crime 7 (1), 2018.

Ekayanti, Rika, "Perlindungan Hukum Terhadap Justice Collaborator Terkait Penanganan Tindak Pidana Korupsi di Indonesia”, Jurnal Magister Hukum Udayana 4 (1), 2015.

Hendra Budiman, “Kesaksian Edisi II”, Jurnal LPSK, Jakarta, 2016.

Nixson Syafruddin Kalo Tan Kamello Mahmud Mulyadi, "Perlindungan Hukum Terhadap Whistleblower Dan Justice Collaborator Dalam Upaya Pemberantasan Tindak Pidana Korupsi”, USU Law Journal 2 (2), 2013.

Octavany, Kadek Yolanda Zara dan Ni Ketut Sri Utari, "Eksistensi Dan Perlindungan Hukum Terhadap Whistleblower Dan Justice Collaborator Dalam Upaya Penanggulangan Organized Crime di Indonesia Pada Masa Mendatang”, Jurnal Hukum Kertha Wicara 5 (2), 2016.

Rizqi Purnama Puteri, Muhammad Junaidi, Zaenal Arifin, "Reorientasi Sanksi Pidana Dalam Pertanggungjawaban Korporasi Di Indonesia”, Jurnal USM Law Review 3 (1), 2020. DOI : 10.26623/julr.v3i1.2283

River Yohanes Manalu, "Justice Collaborator Dalam Tindak Pidana Korupsi”, Jurnal Lex Crime 4 (1), 2015.

Rusli Muhammad, "Pengaturan dan Urgensi Whistle Blower dan Justice Collaborator dalam Sistem Peradilan Pidana”, Jurnal Hukum Ius Quia Iustum 22 (2), 2015. 


\section{Peraturan Perundang-undangan}

Konvensi Perserikatan Bangsa-Bangsa Anti-korupsi Tahun 2003 (United Nation Convention Against Corruption)

Surat Edaran Mahkamah Agung Nomor 4 Tahun 2011 tentang Perlakuan bagi Pelapor Tindak Pidana (whistleblower) dan Saksi Pelaku yang Bekerjasama (Justice Colllaborator )

Undang-Undang Nomor 12 Tahun 2012 tentang Pembentukan Peraturan Perundang Undangan-Undangan

Undang-undang Nomor 31 Tahun 2014 tentang Perubahan Atas Undang-undang Nomor 13 Tahun 2006 Tentang Perlindungan Saksi dan Korban

Undang-undang Nomor 31 Tahun 1999 tentang Pemberantasan Tindak Pidana Korupsi yang telah diperbaharui dengan Undang-undang Nomor 20 Tahun 2001 tentang Perubahan atas Undang-undang Nomor 31 Tahun 1999 